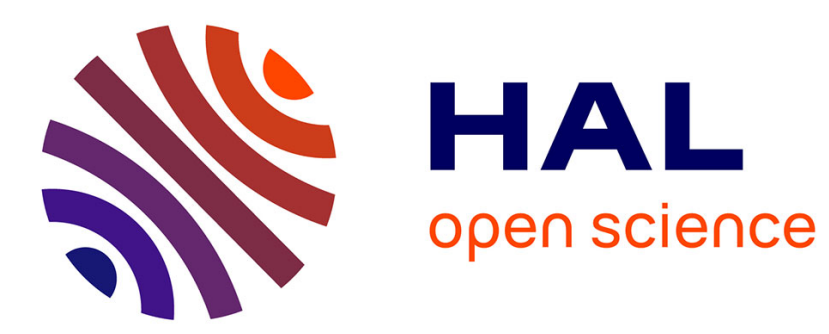

\title{
Effect of substrate bias voltage on the microstructure and tribological properties of $\mathrm{CrN}$ coatings
}

Khalil Aouadi, Corinne Nouveau, Aurélien Besnard, Brahim Tlili, Moez Chafra

\section{- To cite this version:}

Khalil Aouadi, Corinne Nouveau, Aurélien Besnard, Brahim Tlili, Moez Chafra. Effect of substrate bias voltage on the microstructure and tribological properties of $\mathrm{CrN}$ coatings. Annales de Chimie Science des Matériaux, 2016, 40 (1-2), pp.9-15. 10.3166/acsm.40.9-15 . hal-01666604

\section{HAL Id: hal-01666604 https://hal.science/hal-01666604}

Submitted on 18 Dec 2017

HAL is a multi-disciplinary open access archive for the deposit and dissemination of scientific research documents, whether they are published or not. The documents may come from teaching and research institutions in France or abroad, or from public or private research centers.
L'archive ouverte pluridisciplinaire HAL, est destinée au dépôt et à la diffusion de documents scientifiques de niveau recherche, publiés ou non, émanant des établissements d'enseignement et de recherche français ou étrangers, des laboratoires publics ou privés. 


\title{
EFFECT OF SUBSTRATE BIAS VOLTAGE ON THE MICROSTRUCTURE AND TRIBOLOGICAL PROPERTIES OF CrN COATINGS
}

\author{
Khalil AOUADI $^{\mathrm{a}, \mathrm{c}}$, Corinne NOUVEAU ${ }^{\mathrm{a}}$, Aurélien BESNARD ${ }^{\mathrm{a}}$, Brahim TLILI $^{\mathrm{b}}$, Moez CHAFRA $^{\mathrm{c}}$
}

a Arts et Metiers ParisTech, LaBoMaP, 71250 Cluny France.

b Ecole Nationale d'ingénieurs de Tunis, Campus universitaire El Manar II, 2092 El Manar, Tunis, Tunisie.

c Laboratoire de Systèmes et de Mécanique Appliquée, 2078 La Marsa, Tunis, Tunisie.

\begin{abstract}
CrN films were deposited on stainless steel and silicon substrates via magnetron reactive sputtering under a systematic variation of the substrate bias voltage. The influence of this substrate bias voltage on the structural and tribological properties of the films has been investigated. The results indicate that increasing the negative bias voltage has a large influence on the characteristic of the coatings: concerning their microstructure, we observed that the grain size increased. Moreover their coefficient of friction and wear rate are also influenced by the bias voltage.
\end{abstract}

Résumé - Influence de la tension de polarisation du substrat sur la microstructure et les propriétés tribologiques de revêtements $\mathrm{CrN}$. Des revêtements de $\mathrm{CrN}$ ont été déposés sur un acier inoxydable et du silicium par pulvérisation magnétron réactive en faisant varier la tension de polarisation du substrat. L'influence de cette tension de polarisation sur la structure et les propriétés tribologiques des films a été étudiée. Les résultats indiquent que l'augmentation de la polarisation du substrat a une influence importante sur les caractéristiques des revêtements: du point de vue microstructural, on constate l'augmentation de la taille des grains avec la polarisation. Le coefficient de frottement, tout comme le taux d'usure, est fortement influencé par la tension de polarisation du substrat.

\section{INTRODUCTION}

CrN films exhibit good oxidation and corrosion resistance, but because of a wide spread use in tribological applications, it is expected to present good wear resistance under severe tribological conditions such as high load and high temperature [1,2,3]. This coating is obtained by the means of several physical vapor deposition methods, and among them magnetron sputtering $[4,5,6]$. It is known that the structure and properties of magnetron sputtered $\mathrm{CrN}$ coatings strongly depend on the deposition parameters such as relative $\mathrm{Ar} / \mathrm{N}_{2}$ flow rate, temperature, pressure, substrate bias voltage... In particular, bias voltage is a main parameter that affects the properties of coatings due to the enhancement of adatoms mobility and the ion bombardment effect [7]. It is noteworthy that the bias voltage in a magnetron sputtering system controls the microstructure evolution, film texture and also the grain size [8]. Besides, the bias voltage has an effect on the residual stress. Indeed, a compressive residual stress can be beneficial when coated devices are mechanically loaded during 
service due to the increase of their resistance to cracks initiation and growth. However, it may cause cohesive failure during their elaboration [7].

In the present study, $\mathrm{CrN}$ coatings were deposited using an industrial magnetron sputtering system under various substrate bias voltages $(-200,-300,-500$ and $-700 \mathrm{~V})$. The effect of the bias voltage on the microstructure, surface morphology, tribological properties and residual stress of the $\mathrm{CrN}$ layers has been studied.

\section{EXPERIMENTAL DETAILS}

CrN coatings were deposited by DC reactive magnetron sputtering (KENOSISTEC KV40 system), using a chromium target (purity $99.99 \%$ ) in an $\mathrm{Ar}+\mathrm{N}_{2}$ gas mixture. Coatings were deposited on $380 \mu \mathrm{m}$ thick (100) silicon substrates to determine the microstructure and residual stress and on stainless steel $90 \mathrm{CrMoV} 8$ (with the dimensions $15 \times 15 \times 2 \mathrm{~mm}^{3}$ ) used for tribological tests. The substrates were ultrasonically cleaned in acetone and alcohol. A residual pressure of $2.10^{-}$ ${ }^{5} \mathrm{~Pa}$ before deposition was achieved in the chamber. The working pressure was fixed at $0.5 \mathrm{~Pa}$. The Ar and $\mathrm{N}_{2}$ flow rate was $68.8 \mathrm{sccm}$ and $33.3 \mathrm{sccm}$ respectively. Prior to deposition, substrates were etched under argon plasma for $10 \mathrm{~min}$ in order to remove contaminants and ensure good adhesion of the deposited films. During deposition, the target power was fixed at $1500 \mathrm{~W}$ and the substrate temperature was $300^{\circ} \mathrm{C}$. In order to study the effect of the substrate bias voltage, different values ranging from -200 to $-700 \mathrm{~V}$ were applied. The duration of deposition of all coating is 2 hours.

The surface morphology and the cross section of the coatings were investigated with fieldemission scanning electron microscopy (JEOL JSM 6400F). Chemical composition was determined by energy dispersive spectroscopy (EDS).

The friction and wear tests were ran in a standard ball-on-disc rotative tribometer using of $2 \mathrm{~N}$ load, a sliding speed of $3 \mathrm{~cm} / \mathrm{s}$ and $200 \mathrm{~m}$ as the sliding distance against an alumina ball $\left(\mathrm{Al}_{2} \mathrm{O}_{3}\right)$ (diameter $=6 \mathrm{~mm}$ ). The observation of the coated surfaces and of the balls after the wear tests was performed using a 3D optical profilometer (VEECO, Wyko NT-1100).

\section{RESULTS AND DISCUSSION}

\subsection{Microstructure}

Figure 1 represents the cross sectional morphologies of $\mathrm{CrN}$ coatings deposited at various bias voltages.
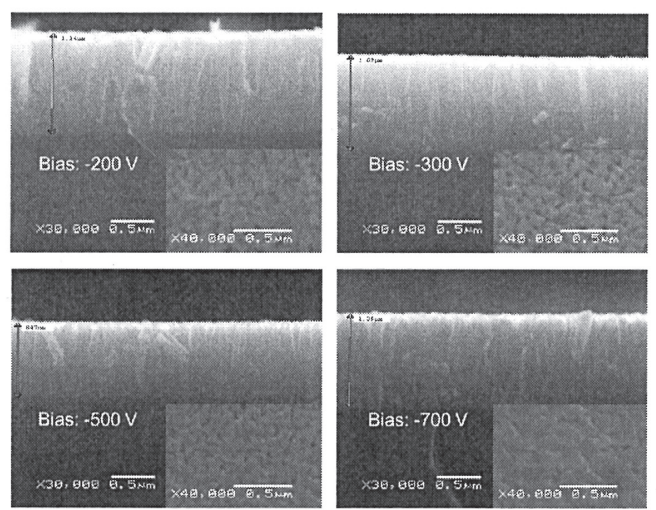

Figure 1. Cross-section and surface of $\mathrm{CrN}$ coatings under different bias voltage 
SEM analysis showed that all the coatings have a columnar morphology and their thickness is within the range of $0.9-1.14 \mu \mathrm{m}$ (Table I).

Table I: Thickness of $\mathrm{CrN}$ coatings versus bias voltage

\begin{tabular}{|l|l|l|l|l|}
\hline Bias voltage $(\mathrm{V})$ & -200 & -300 & -500 & -700 \\
\hline Thickness $(\mu \mathrm{m})$ & 1.14 & 1.09 & 0.87 & 1.05 \\
\hline
\end{tabular}

A comparison of the thickness shows that it slightly decreases when the bias voltage increases from -200 to $-700 \mathrm{~V}$ except for $-500 \mathrm{~V}$ where the thickness drops to $0.9 \mu \mathrm{m}$. A possible explanation of this phenomenon could be that higher substrate bias may exert a drastic impact on the metallic ions to reduce the deposition rate [9].

We can observe in the inserts on figure 1 the surface morphologies of the $\mathrm{CrN}$ coatings. A change of the grain size is obvious. Indeed, grains are denser and finer for the coating synthesized at $-200 \mathrm{~V}$. Coatings obtained with bias voltages from -300 to $-700 \mathrm{~V}$, present a larger grain size. The increase of the bias voltage of the substrate has a main influence on the coatings grain size.

\subsection{Residual stress}

Residual stress is determined using the Stoney formula. The strain radius is measured from optical profilometry images of the whole surface before and after coating. The evolution of the stress in compare to the negative bias voltage is presented in figure 2 .

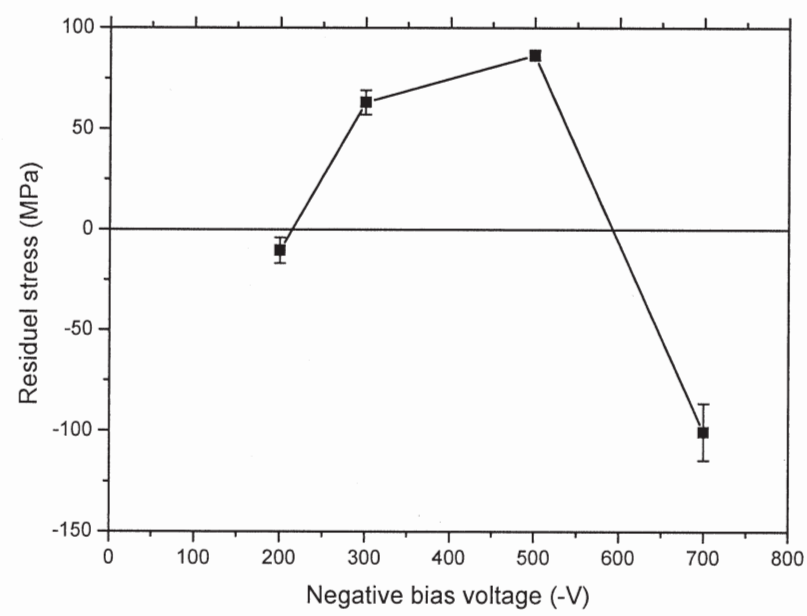

Figure 2. Residual stresses of $\mathrm{CrN}$ films deposited under different substrate bias voltages

Internal stress ranges from $86.4 \mathrm{MPa}$ to $-100 \mathrm{MPa}$. One can note that by increasing the bias voltage from -200 to $-500 \mathrm{~V}$, the low compressive stress changes to tensile stress. Between -500 and $-700 \mathrm{~V}$ the internal stress changes and is compressive again at $-700 \mathrm{~V}$. Generally, the residual compressive stresses occur when the deposition film growth is done under an energetic ion bombardment (energies of 10 or $100 \mathrm{eV}$ ). Indeed, in this case many defects occur such as defects of stacks, grains low angle..., which causes the deformation of the mesh and produces growth stress. According to Wang and al. [10] internal stress can be relaxed by thermal peaks, resulting in the 
release of the tension generated by the contact between the atoms and the substrate. As a consequence, the residual stress in the coating will decrease at high substrate bias voltage. Also the decrease of the residual stress may be due to the increase of the grain size and the stress relaxation [11]. We observe a strong decrease of residual stress between -500 and $-700 \mathrm{~V}$. This could be attributed to the ion peening effects [12].

We also note that for $-700 \mathrm{~V}$ the compressive residual stresses are higher compared to that of $200 \mathrm{~V}$. This is attributed to the defect density induced by ion bombardment [8].

\subsection{Tribological properties}

\subsubsection{Friction}

The friction coefficients of the $\mathrm{CrN}$ films under different bias voltages are shown on figure 3.

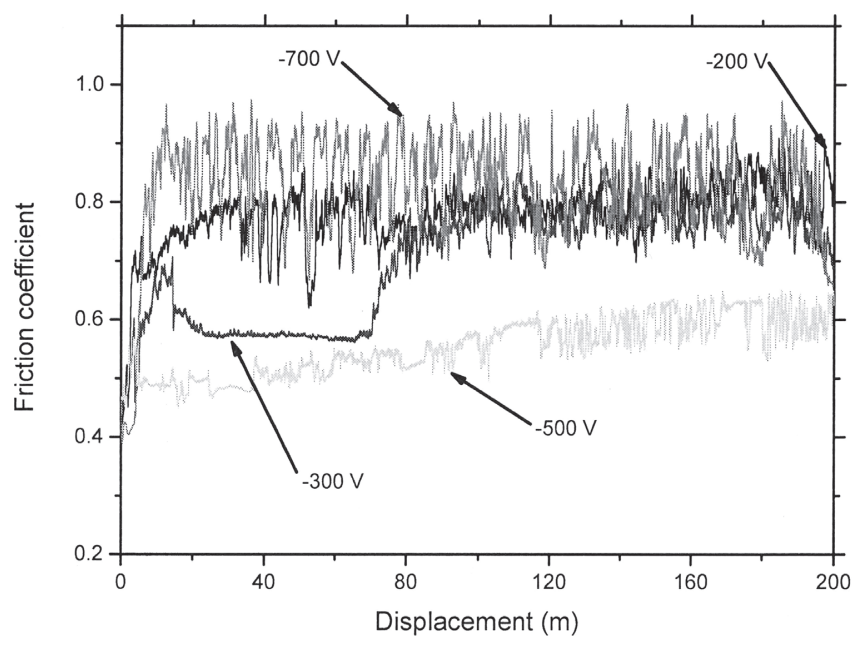

Figure 3. Evolution of the coefficient of friction for different bias voltages

We observed that the coefficient of friction increased initially, as a usual transition or break-in period. Then, it stabilizes after a certain distance according to the surface morphology and state of each coating (figure 3).

The friction coefficient of $\mathrm{CrN}$ compared to the bias voltage varies between 0.5 and 0.8 , indicating a strong influence of this parameter on the friction mechanism. Indeed, for $\mathrm{CrN}$ coatings obtained with a bias of -200 and $-700 \mathrm{~V}$, the friction coefficient remains stable around 0.8 after a short sliding distance of $15 \mathrm{~m}$. This is relevant with the compressive stress state observed for these coatings. It can be also noted that for the films synthesized with a bias of $-700 \mathrm{~V}$ and which presents the highest compressive stress, the dispersion of the friction coefficient is wider than for the one realized at $-200 \mathrm{~V}$ where the stress is approximately equal to zero. It suggests that the wear mechanisms are different: for $-700 \mathrm{~V}$ the coating is probably destroyed completely under the ball and the test is performed on a steel track with steel and coating debris. For $-200 \mathrm{~V}$, the coating is removed partially and progressively and the test is performed on the coating and on steel and coating debris located in the delaminated zone. 
For the coating synthesized at $-300 \mathrm{~V}$, three zones are observed: first a sharp increase with same aspect as the $-200 \mathrm{~V}$, indicating the beginning of the film delamination. Then a second zone with a stable friction coefficient of 0.58 during $50 \mathrm{~m}$, without strong wear of the film is observed. Finally at $75 \mathrm{~m}$ the friction coefficient increases suddenly to 0.8 , due to the film wear with a partial delamination.

For the coating synthesized at $-500 \mathrm{~V}$, the friction coefficient increases slightly during the test from 0.5 to 0.6 . This range of values, similar as in the second zone of the $-300 \mathrm{~V}$ friction test, corresponds to the friction coefficient of the $\mathrm{CrN}$ film against an alumina ball. Similar results were obtained by Tlili [13] and Benlatreche [14] who observed a friction coefficient of 0.58 and 0.55 respectively. Zhou et al. [15] showed that the $\mathrm{CrN}$ coefficient of friction is between 0.5 and 0.65 , depending on the deposition conditions and the applied normal load during the sliding test.

The decrease of the friction coefficient in compare to an increasing negative bias from -200 to $-500 \mathrm{~V}$ in this work has also been found by other studies $[11,16]$. This behavior is not observed for a negative bias of $-700 \mathrm{~V}$. It can be explained by a change in the structure and the growing mode induced by the ion bombardment after a certain level. This result can also be related to the evolution of the thickness of the films presented in Table I.

\subsubsection{Wear}

The wear rate, calculated from wear profiles, of the $\mathrm{CrN}$ coatings is presented on figure 4 .

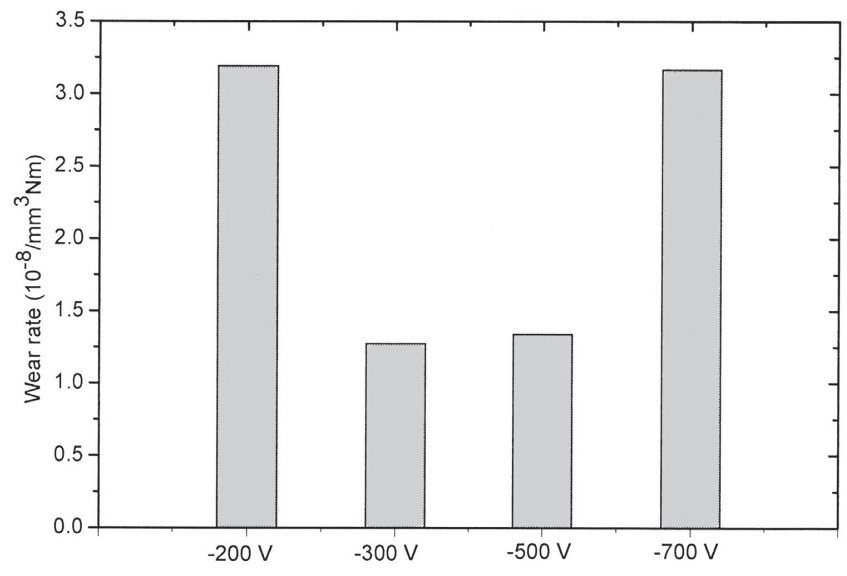

Figure 4. Wear rate of $\mathrm{CrN}$ coatings under different bias voltages

A strong decrease of the wear is observed by increasing the bias voltage from -200 to $-300 \mathrm{~V}$. The wear rate remains constant by increasing the voltage to $-500 \mathrm{~V}$ and presents a major increase for the coating made at $-700 \mathrm{~V}$. The wear rate is consistent with the friction results presented in 3.3.1. The two coatings $(-200$ and $-700 \mathrm{~V})$ with a high wear rate have a high friction coefficient and the one performed at $-500 \mathrm{~V}$ has the lowest wear rate and the lowest friction coefficient. For the deposition at $-300 \mathrm{~V}$ the wear rate is low, but we know from friction measurement that a delamination (partial or total) occurred during the test. These observations are similar to those of Kok et al [17], who proved that the wear of the coatings is in a good correlation with the frictional performance; especially for films, higher the friction coefficient is, higher the wear rates is. 
Moreover, several studies showed that the wear rate decreased when the negative bias voltage increased $[16,18]$. This is consistent with the results of the samples deposited with bias voltages from -200 to $-500 \mathrm{~V}$, but not for $-700 \mathrm{~V}$. It has to be related to the change of structure and characteristic (thickness, stress) previously observed. Kong et al. [19] also reported a change of crystallographic orientation of $\mathrm{CrN}$ film with the increase of the negative bias voltage.

Figure 5 shows the chemical elements in and around the wear track after the tribological tests. Light grey represent the presence of the considerated element, black his lack.
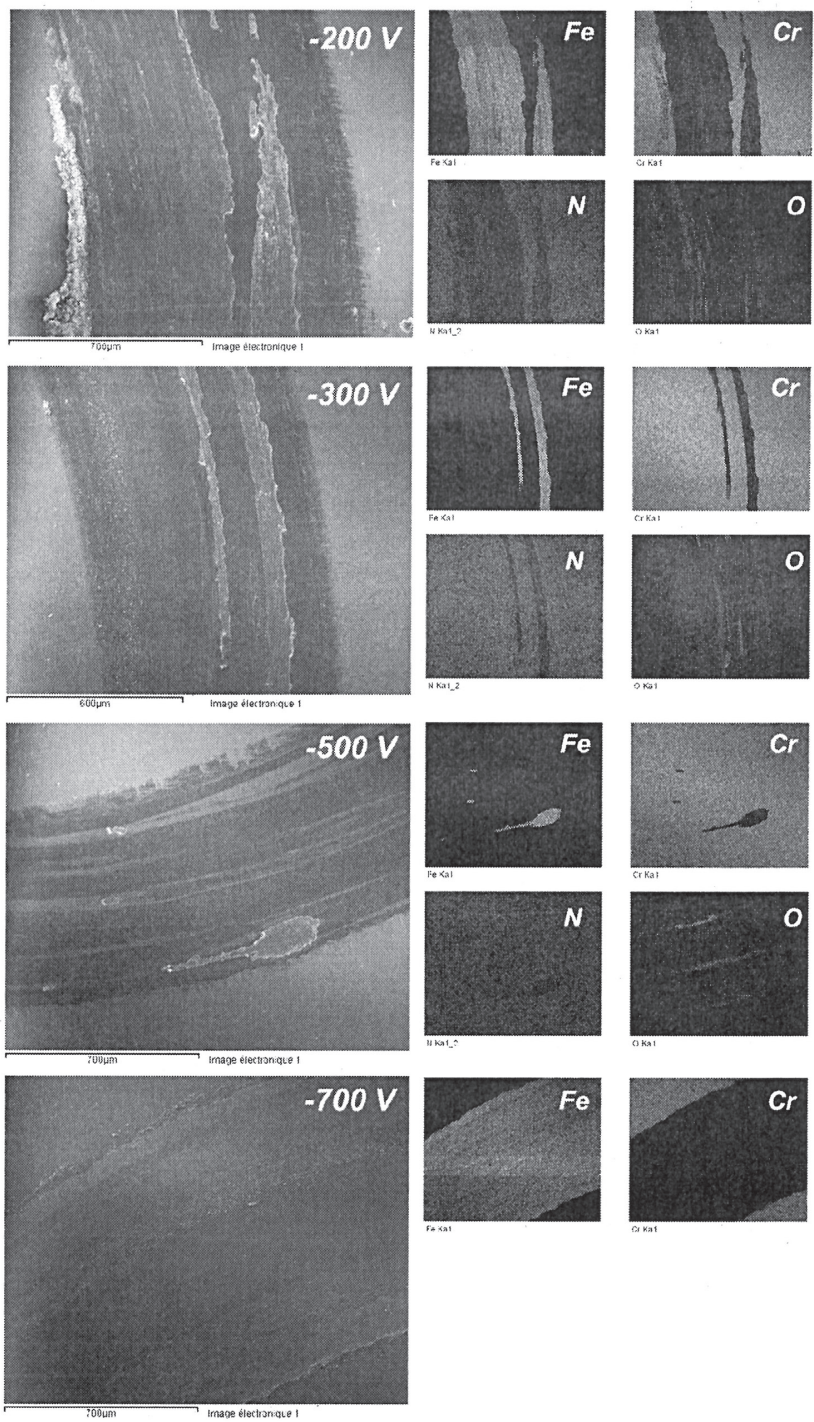

Figure 5. SEM images and EDX element map of wear track obtained after rubbing tests of CrN coatings (bias voltage of $-200,-300,-500$ and $-700 \mathrm{~V}$ ) against an alumina ball. 
For all samples, the presence of iron proves the delamination of the film. Besides, we observe that a small oxidation of the iron occured during the test due to the contact with the air and the local heating of the contact area. These images are consistent with the wear rate measured. The coatings synthesized under -200 and $-700 \mathrm{~V}$ show major delamination under the friction track (total for $700 \mathrm{~V}$, partial for $-200 \mathrm{~V}$ ). Deposition performed under -300 and $-500 \mathrm{~V}$ produce adhesive coatings. The iron is detected in thin and continuous tracks for the $-300 \mathrm{~V}$ and only at located points for the $500 \mathrm{~V}$ polarized coating.

\section{CONCLUSION}

This study shows the strong influence of the substrate bias voltage on the tribological and morphological properties of CrN PVD coatings. The negative bias voltage has a main effect on the grain size. Indeed, the grain size of the $\mathrm{CrN}$ coatings increases with the negative substrate bias voltage. Concerning friction tests, the lowest coefficient of friction and wear rate were obtained for $\mathrm{CrN}$ layers realized at $-500 \mathrm{~V}$. After the friction tests, the $\mathrm{CrN}$ film synthesized at $-700 \mathrm{~V}$ is totally removed from the substrate while the $\mathrm{CrN}$ film deposited at $-500 \mathrm{~V}$ has the best wear resistance.

A drastic change of structure, which has an impact on all properties, is found after a certain level of bias voltage (between -500 and $-700 \mathrm{~V}$ in this study).

\section{REFERENCES}

[1] Z.B. Qi, B. Liu, Z.T. Wu, F.P. Zhu, Z.C. Wang, C.H. Wu, Thin Solid Films 544 (2013) 515520.

[2] C. Petrogalli, L. Montesano, M. Gelfi, G.M. La Vecchia, Surf. Coat. Tech. 258 (2014) 878885.

[3] T. Polcar, N.M.G. Parreira, R. Novak, Surf. Coat. Tech. 201 (2007) 5228-5235.

[4] F.B. Wu, J.J. Li, J.G. Duh, Thin Solid Films 377-378 (2000) 354-359

[5] M. Vite, M. Moreno-Rios, E.A. Gallardo Hernandez, J.R. Laguna-Camacho, Wear 271 (2011) 1273-1279.

[6] H. Scheerer, H. Hoche, E. Broszeit, C. Berger, Surf .Coat. Tech. 142-144 (2001). 1017-1022.

[7] M. Oden, J. Almer, G. Hakansson, Surf. Coat. Tech. 120-121 (1999) 272-276.

[8] Q. Kong, L. Ji, H. Li, X. Liu, Y. Wang, J. Chen, H. Zhou, Mat. Sci. Eng. B 176 (2011) 850854.

[9] C.H. Hsu, K.L. Chen, Z.H. Lin, C.Y. Su, C.K. Lin, Thin Solid Films 518 (2010) 3825-3829.

[10] Q.M. Wang, S.H. Kwon, K.H. Kim, Trans. Nonferrous Met. Soc. China, 21 (2011) 73-77.

[11] F. Lomello, F. Sanchette, F. Schuster, M. Tabarant, A. Billard, Surf. Coat. Tech. 224 (2013) 77-81.

[12] C.T. Lee, W.H. Cho, M.H. Shiao, C.-N. Hsiao, K.S. Tang, C.C. Jaing, Procedia Eng. 36 (2012) 316-321.

[13] B. Tlili, PhD, Arts et Metiers ParisTech/ENIT, 2010, number 2010-ENAM-0059.

[14] Y. Benlatreche, PhD, Arts et Metiers ParisTech, 2011, number 2011-ENAM-0014.

[15] F. Zhou, K. Chen, M. Wang, X. Xu, H. Meng, M. Yu, Z. Dai, Wear 265 (2008) 1029-1037.

[16] M. Hua, H.Y. Ma, J. Li, C.K. Mok, Surf. Coat. Tech. 200 (2006) 3612-3625.

[17] Y.N. Kok, P.Eh. Hovsepian, Q. Luo, D.B. Lewis, J.G. Wen, I. Petrov, Thin Solid Films 475 (2005) 219-226.

[18] J. Romero, M.A. Gómez, J. Esteve, F. Montala, L. Carreras, M. Grifol, A. Lousa, Thin Solid Films 515 (2006) 113-117.

[19] Q. Kong, L. Ji, H.Li, X. Liu, Y. Wang, J. Chen, H. Zhou, Mat. Sci. Eng. B 176 (2011) 850854. 